\title{
Robert Boyle and the Art of Occasional Meditation
}

\author{
RAYMOND A. ANSELMENT \\ University of Connecticut
}

L'ouvrage de Robert Boyle, Occasional Reflections upon Several Svbiects, publié en 1665, permet d'estimer la contribution de son auteur à la méditation occasionnelle, de plus en plus courante au dix-septième siècle. Dans le cadre d'un commentaire plus large, l'introduction et le Discourse qui précède la collection, constituent la plus importante discussion de ce genre à cette époque. Au centre de son appréciation de l'exercice méditatif, l'emphase que Boyle y met sur une « manière de penser $\gg$ ouvre le genre de la méditation occasionnelle sur davantage que des préoccupations pieuses et met de l'avant une habitude de penser proprè à la philosophe morale et naturelle. Les méditations elles-mêmes, bien qu'inégales, contribuent à une meilleure compréhension de l'art dont elles relèvent, et complètent le propos de Boyle.

$\mathrm{W}$ Then Robert Boyle's Occasional Reflections upon Several Svbiects was published in 1665 along with A Discourse About such kind of Thoughts, he acknowledged Joseph Hall's contribution to this seventeenth-century genre. Bishop Hall's The Art of Divine Meditation $(1606,1633)$ and the three editions of Occasional Meditations $(1630,1631,1633)$ warrant this recognition. Contemporaries noted their influence or praised "the divine, and eloquent Contemplations, and occasional Meditations of Doctor Hall"; and modern scholars emphasize Hall's importance in the development of Protestant meditation. ${ }^{1}$ Boyle's acknowledgment, however, is problematic. In distinguishing his occasional meditations from those of Hall, Boyle contends "that not to Prepossess or Byass my Fancy, I purposely (till of late) forbad my self, the perusing of that Eloquent Prælates devout Reflections." 2 This attempt to distance himself from Hall has met with some skepticism from Boyle scholars who concede that "it seems almost inconceivable that Boyle was not influenced by Hall" and who contend that the bishop's earlier work "had provided a model for Boyle's Occasional reflections." 3 Whether the meditations did indeed develop independently, Boyle's explanation is an attempt to justify his use of dialogue so that "the Reader will be less startled at my deviating in this, and other things, from Bishop Hall's way of writing Occasional Meditations" (10). His uniqueness "in this, and other things," merits attention. The lengthy Introduction and Discourse offer the most substantial 
discussion of the occasional meditation in the seventeenth century, and the 76 reflections or meditations that follow illustrate Boyle's significance. The fifteen that he wrote on a life-threatening ague in the form of epistles to his sister Katherine Jones, Lady Ranelagh, and the 21 comprising a narrative describing a morning spent fishing, while noteworthy, are in their epistolary and narrative formats less typical of the genre than the other 40 meditations. Together with the Introduction and Discourse, these provide an occasion to appreciate Boyle's contribution to the art of the occasional meditation. ${ }^{4}$

Whereas the reflections on the ague were presumably written at the time of a severe illness in 1649, and those related to angling were probably completed in the Interregnum, the other 40 were composed over a number of years. Gilbert Burnet, who preached the sermon at Boyle's funeral, notes in his memorandum that the occasional meditations were "writ" before the age of 22.5 Boyle refers to the reflections in his collection, and implicitly six others that remained in manuscript, as "Trifles" and "Censurable Things," some of them written before " $m y 19^{\text {th }}$ or $20^{\text {th }}$ year" and "some of a much fresher date" $(12,9) .{ }^{6}$ The titles of several are dated in the 1640s, and another concerns an event that occurred in 1662; their placement in the edition provides no certain clue to their chronology. The Introduction prefacing the Discourse and Reflections describes their order as "Casual," though there may be some suggestion of development, if not chronology. The 40 reflections are gathered in sections of ten: between the first and second of these groups Boyle inserts those "Upon the Accidents of an Ague"; the final two sections of ten follow the angling pieces. The prefatory comments indicate the ague and angling meditations are better suited for readers "of the more intelligent sort, or good Proficients already"; others are "of a more familiar sort, \& easier to be lighted on" (9). The last ten reflections, in any case, approach the complexity and maturity evident in the angling narrative. Boyle's characterization of all 76 in the collection as occasional reflections, occasional meditations, and meletetics, however diverse they may be, links these 40 especially to an established tradition.

The genre commonly associated with Hall and practised by other seventeenthcentury authors turns on a distinction from formal meditation. By its nature, contemporary commentary notes, the occasional meditation resists the formality of the meditative practice variously described as set, solemn, or deliberate. Bishop Hall stresses "there may be much use, no rule" for the meditative mode that depends upon "suddain invention not composed by study." 7 It is essentially occasional or, in the often-repeated synonyms, extemporal, sudden, quick, rapt, and ejaculatory. Hall offers the further distinction between meditation "either 
extemporal and occasioned by outward occurrences offered to the mind; or deliberate and wrought out of our own heart." ${ }^{8}$ Richard Baxter, a seminal figure in the development of Protestant meditation, likens the difference to that between ejaculatory and set prayer, short discourse and extended sermons. ${ }^{9}$ Meditation "called extemporall, occasionall, or sudden," Richard Rogers observes, is "occasioned by such things, as by the prouidence of God doe offer themselues to our senses, eyes, eares, \&c; as wee goe about the duties of our callings, or be exercised in some honest and lawfull recreation." ${ }^{10}$ Isaac Ambrose incorporates Rogers's early seventeenth-century definition in his 1657 discussion, and the statement is reproduced almost verbatim in John Ball's 1660 A Treatise of Divine Meditation. ${ }^{11} \mathrm{~A}$ copy of this work is listed in the catalogue of what may have been Boyle's library, ${ }^{12}$ and he was well-acquainted with Richard Baxter, who wrote to him applauding the Occasional Reflections. He probably also knew Nathanael Ranew, whose lengthy Solitude Improved by Divine Meditation (1670) had its genesis in conversations with Boyle's sister Mary Rich. Boyle may also have read some of the occasional reflections he notes "considerable Persons" have written "of late" (20). And even though he claims not to be influenced by Hall's publications, Boyle admits in the Introduction that the bishop's "very Generall Tearms" of praise prompted him "to Display the Usefulness of the way of thinking" (16). The significance of Boyle's advocacy lies less in its originality than in the weight he gives to what he repeatedly calls a "way of thinking."

A Latin passage on the title page from Seneca's Naturales Quaestiones offers an indication of the collection's intent. Seneca's association with stoicism suits the tenor in several of the reflections, and Boyle shares a similar interest in the moral contemplation of nature. ${ }^{13}$ By the time the loose papers were gathered together for publication, Boyle had become increasingly involved in the scientific studies that would ultimately gain him considerable renown as a natural philosopher. He would never abandon, however, the concern with ethics and piety central to his earlier moral essays and initial publications. ${ }^{14}$ Some of the meditations in Occasional Reflections date from the years in which this interest was dominant, and the Discourse itself develops several positions set forth in essays written during this period. In the questions Seneca raises from nature, Boyle may have found a kindred sensibility. The passage from Naturales Quaestiones prominent on the title page emphasizes the need for moral consideration: "Something must be joined to all things and all words to achieve salvation. When we journey through the secrets of nature, when we treat divine matters, the mind must be protected from its evils and continually strengthened" $(3,4){ }^{15}$ Boyle's understanding of nature and his emphasis on divinity 
and the mind are in their own way an attempt to bring together the two realms of the moral and natural philosopher.

His contemplation of nature's secrets, which he likens to "a Book of Hieroglyphicks" $(27,39)$, is closely linked to a traditional view of the occasional meditation. In providing the synonym "Meleteticks," the Introduction defines a practice that has "supply'd us with Religious and hansome Reflections, upon the most Obvious Works of Nature, and the most Familiar Occurrences of humane Life" (19). The same paragraph compares the world to "a great Conclave Mnemonicum, and a well furnished Promptuary, for the service of Piety and Vertue" (19). ${ }^{16}$ Comparisons later in the Discourse liken nature to a book, a metaphor familiar in commentary on the occasional meditation. Boyle's belief that those who reflect upon "the World it self, and the Actions of the Men that live in it" (26) have in effect a library with many open books affirms a common view. More emphatically than previous commentary, however, he insists "the World is the great Book, not so much of Nature, as of the God of Nature" for all who possess the ability and willingness to decipher its hieroglyphs (39). ${ }^{17} \mathrm{~A}$ variation of this conceit adds that the apt reflector can "make the World vocal," giving creatures and occurrences tongues that can "read him Lectures of Ethicks or Divinity" (22). While the notion of listening, like that of reading, also has precedents in seventeenth-century commentary, Boyle gives both greater prominence: "all kinds of Creatures in the world" can be transformed "not onely into Teachers of Ethicks, but oftentimes into Doctors of Divinity" (28). ${ }^{18}$ This transformation he likens to the familiar difference between the ant that takes from nature only what it needs and the bee that creates valuable honey in the process $(28,52) .{ }^{19}$ Boyle departs from earlier commentators, though, in his willingness to be considerably more inclusive in what the reflection can derive from the occasion: "the discovery or illustration of Oeconomical, Political, or Physical matters" (30).

The transformation of the occasion is for him the redemptive use of time. Foremost among the justifications in the Discourse is the banishment of idleness. In a phrasing that later authors would adopt, Boyle locates the extemporaneous in the "uncertain Parentheses" of daily life. ${ }^{20}$ His emphasis on the need to employ even the "smaller parcels of Time" (24) has a moral urgency not apparent to the same degree in Robert Hall's comment that his father Bishop Hall was "wont to improve those short ends of time" he had "stolen from his more important avocations." ${ }^{21}$ In an earlier essay "Of Time and Idleness," Boyle had advocated at length the need to profit from "scraps of Time"; another essay from this period, "The Doctrine of Thinking," values especially the composing of occasional meditations as a desirable means of using the "shreds of Time." 22 When Boyle justifies his own commitment 
to this genre, a passage from the first of these becomes with little modification an important focus: "these uncertain Parentheses, (if I may so call them) or Interludes, that happen to come between the more solemn Passages (whether Businesses, or Recreations) of humane Life" (24). ${ }^{23} \mathrm{He}$ also adapts the metaphoric language in contemporary commentary, notably figurative mirrors and telescopes. ${ }^{24}$ For the "skilful Contemplator," especially those inspired by devotion, the fragments of time become truly insightful: "both Looking-glasses, to dress our Souls by, and Perspectives to discover Heavenly wonders, and Incentives to inflame our hearts with Charity and Zeal" (24). Commonplace is the further comparison likening meditation to the wings and ladder that lead toward heaven. ${ }^{25}$ The "short Flights Heaven-wards" through extemporaneous reflection and "other mental Acts of Piety," Boyle concludes, are for the devout an opportunity whereby they "may not onely rescue these precious Fragments of Time, but procure Eternity with them" (25).

The extemporal nature of the meditation significantly determines its expression. The moment and the chance of the occasion encourage spontaneity, though there is, of course, a difference when the meditative experience is set down in writing. In that case, Boyle's attention to what he characterizes as "a loose and Desultory way of writing” (9) is complicated by a defensiveness at odds with its publication. With considerable, even tiresome repetition, his opening address to his sister Lady Ranelagh and the ensuing Introduction suggest a reluctant author whose "Trifles" were sent "unfinished and unpolished" (5) to the publisher in response to the encouragement of others and against his better judgment. Boyle also reminds his readers several times that the occasional reflections are a "Divertisement" intended for his own amusement. Yet he is also aware of the audiences for whom his meditations are in fact written. The comments on style and the sensitivity to decorum in the Introduction reveal an unusually thoughtful and extended consideration. While Boyle may seem unduly apologetic in calling attention to his lack of stylistic uniformity, he refuses to attribute any shortcomings solely to the immature and unrefined quality of the writing. In composing reflections that "commonly make use of things rather out of haste than choice, as frequently being but the first thoughts," he suggests that such meditations should "cherish piety, than that they express wit" (31). The contemporary preference was for a plain style, "no ornament but fervency." ${ }^{26}$ The Introduction, however, notes that while some of the meditations aim to express piety rather than eloquence, in others "a different style was thought fitter" (8).

Though Boyle may have in mind the audiences of the ague and angling sections, he also recognizes that the subjects of the reflections and not simply the extemporaneous contexts determine the expression. He further acknowledges 
that in establishing the Protasis, what he calls the "Ground-work of all the rest" (12), some of the subjects may seem "very Mean, and Trivial" and some of the language may seem "too Elaborate, or too Pompous, for the Themes" $(9,13)$. The concession anticipates the criticism leveled against his occasional reflections in the seventeenthand early eighteenth-century parodies by Samuel Butler and Jonathan Swift. ${ }^{27}$ But in his own defense Boyle invokes a principle of decorum or "sutableness to the Theme, how mean soever it be" (12). He contends that the Apodosis or "Application" may be different in both nature and expression, justifying in its quite dissimilar style a degree of wit and ornamentation. The ideal is "apt Similitudes, pertinently appli'd" (19), reflections that are "not strain'd, nor too far fetch' d" (13). The ultimate justification of this "Figurative and Indirect" expression is the biblical parable. ${ }^{28}$ Like others in the seventeenth century, Boyle sees in Christ's way of embodying the serious and sacred in similitudes a form of instruction that (in the phrasing of the Discourse) inveigles the instructed into virtue and piety (20).

But the Discourse makes apparent that the essential focus remains the meditator. Boyle offers what he calls a series of "inducements" that justify the occasional meditation in ways Hall does not. Where The Art of Divine Meditation, in Boyle's view, considers the value of this genre only generally, the Discourse develops at length its advantages. The tack is decidedly different from the only other discussion of considerable substance, Ball's A Treatise of Divine Meditation. The seven benefits listed in the book that Boyle may have read tend, not unexpectedly, to emphasize spiritual significance. Through extemporary reflection, the earthly becomes for Ball a means of communion that enkindles the spirit and promotes prayer. An awareness of the self, especially of humility, adds to the beneficial lessons learned from contemplating nature's "large volume." 29 Boyle shows an appreciation of the piety and devotion common to other contemporary justifications, though he remains unique in the emphasis the Discourse places on "the way of thinking."

In doing so, Boyle gives new richness to the role of the mind in the meditative experience. Hall's fundamental distinction between the extemporal and the deliberate- "outward occurrences offered to the mind" as opposed to those "wrought" from the heart-refines the accepted belief that meditation in general was a "bending of the mind" upon spiritual concerns. ${ }^{30}$ Later commentaries on the occasional meditation note a characteristic "sudden fixing of the mind," a "profitable minding," or a "serious bending of the mind." ${ }^{11}$ Some attempt is also made to differentiate meditation from study, which turns on the difference between the head and the heart or discovering the truth as opposed to improving the truth spiritually. ${ }^{32}$ While Boyle never minimizes the moral and spiritual significance 
of the occasion, more than any previous seventeenth-century writer he considers the salutary nature of the extemporal mind, the benefit not only of "mental Acts of Piety" (25) but of "Mental Exercise" (29). Appropriately, at the stage in which he was conscious of his growing image as a natural philosopher, Boyle appreciates the occasional meditation as a means of bringing about "a thinking and a reflecting Person" (33) capable of probing the mysterious realm of nature and discovering "the Wisdom, Power, and Goodness" of its creator (34).33

The first of Boyle's four advantages justifying this "way of thinking," the banishment of idleness, differs in emphasis from earlier seventeenth-century commentaries. Thomas Gouge recognizes that the mind engaged in meditative reflection eschews the danger of becoming idle. ${ }^{34}$ Richard Baxter's encouragement to readers of The Saints Everlasting Rest to "redeem time as much as they can" by taking "opportunities [to meditate] as they fall" anticipates Boyle's belief that the meletetics he advocates in the parentheses and interludes of daily business will avoid the wasting of fragmentary time and "redeem so many Portions of our Life" (24).35 Moments spent extemporaneously, likened to mirrors and telescopes, recall the importance others place on the meditative perspectives of the self and of heaven. The enkindling of the heart and the momentary flights of the soul are also not unique to the Discourse. But as a prelude to the further arguments, the initial justifications for spontaneous meditating and thinking underscore rhetorically the need and even obligation to transform the occasion and its objects into "pious Uses" whereby the mind, far from being distracted, can be elevated and animated (25).

Though the end is always moral or spiritual, the next section of the Discourse, or the second advantage, shows that morality and devotion can be delightful. The pleasure derives in part from unending variety and surprise. Within the metaphor of the library open to reflection, Boyle finds delight simply in the unlimited books of knowledge and the insights they offer the apt reader. The variety celebrates a new and comprehensive understanding of the occasional reflection. When Boyle suggests that the mutable fate of governments merits equal attention with life's commonplace, the inclusiveness is not limited to cultivating piety or religious devotion. Unlike earlier writers, he grants considerable leeway to those willing "to make of the Objects they contemplate not onely a Theological and a Moral, but also a Political, an Oeconomical, or even a Physical use" (30). Boyle also remains unique in the premium he places on the pleasurable act of discovery, "the pleasantness of the Mental Exercise" (29). Sudden reflection or thinking promotes a "Dexterousness and Sagacity" (27) that are themselves satisfying. In the same vein, though somewhat more strained, the Discourse sees additional merit in "the sweetning of Reproofs" 
(29) that arises from faults apparent upon self-reflection. Boyle's interest in the delight and value of understanding, which he likens to the bee that improves as it transforms, emphasizes, moreover, the transformation possible in the mind of the meditator.

He extols the advantages to the mind's faculties in the third and most original in the series of advantages. Here, interest in the ways reflective thinking fosters a desirable habit of mind departs significantly from previous commentaries on the occasional meditation. Besides the delight in variety, the seemingly unlimited range of subjects encourages in the observer an attentiveness that strengthens the reasoning essential to "the bringing of a man to be a thinking and a reflecting Person" (33). The facility acquired gradually through reflection leads in this view to "a readiness of Conception." The premium here is on wit, which Boyle defines as the nimbleness of subtle conceiving and neat expression (35). The "certain Suppleness of Style" depends upon the reciprocal relationship of the "Inventive faculty" and the occasion: variety requires and encourages a "pliant" style. The diversity of subject and the practice of reflection also reinforce the importance of the comparative. The occasional meditation by its nature depends upon the analogous, which for Boyle enriches the wit by providing a storehouse of valuable comparisons. "Plausible Argument, dress'd up in fine Similitudes," quite simply, has a greater rhetorical appeal than "naked Syllogism" (36). But he is also aware, if only in passing, of the contemporary distinction between wit and judgment, the ability to perceive as well as distinguish similarity and disparity; and he offers the token assurance that the faculty of judgment too is enhanced through reflection. Appropriately, the third section ends in similitude, likening the world to a book and comparing wisdom to the elixir of alchemy. While neither metaphor is original, no author offers a comparable awareness of the understanding and transformation possible in contemplating the common and trivial, a betterment not only of the soul but of "the most lovely Qualities of the Mind” (39).

The final advantage lies in the will and the affections: "good thoughts" lead to "good motions." The conclusion is in keeping with the well-established belief that meditation begins with understanding and ends in affection, two faculties of the soul..$^{6}$ In focusing attention on "This friendly property to Devotion" (41), the Discourse concludes on another traditional note: the occasional meditation enhances pious souls - the "devout Reflector" - by endearing them to God and enabling a "free communion" with him. Boyle links the union possible, if only momentarily, with the "way of thinking" he twice calls "Heavenly Mindedness." The phrase occurs often in the seventeenth century, commonly to accentuate the limitations of temporal 
existence and "the onely way to chearfulness." 37 Baxter later specifically refers to meditation as "the exercise of Heavenly-mindedness," and Ranew in his treatise uses this phrase to describe the "heavenward" benefit. ${ }^{38}$ Boyle anticipates both authors in understanding its meaning as "a Disposition and a Readiness to make Spiritual uses of Earthly things" (52). When in the last paragraph he recalls the figurative bee, sees the world as a pulpit, and likens occasional meditation to Jacob's ladder, he relies upon familiar metaphoric language. Boyle's emphases, however, are noteworthy in their reinforcement of that "certain frame, or temper, which may not improperly be called Heavenly Mindedness" (52).

While the ability to reflect piously upon the occasion or occurrence remains the ultimate benefit, the attention to "this way of thinking" confirms an essential interest as well in cultivating or acquiring "an aptitude and disposition." The gains are for Boyle more than moral and spiritual. The Discourse together with the Introduction stands apart from contemporary commentary and merits consideration as a significant appreciation of the meditative exercise itself. Well used, intervals of time can be turned to the benefit of the mind and the soul, opening the meditation to other than pious concerns and promoting a thoughtful and reflective sensibility. The advantages Boyle sets forth in the Discourse often in terms of reasoning and understanding suit both the moral and natural philosopher who thereby strengthens the facility with which nature's book can be meaningfully read.

Though he acknowledges that the Discourse should be completed with a second part concerning the "Method" for "Cultivating this sort of Meditations" (21), the collection of occasional reflections offers the only measure of what this unwritten portion might have entailed. Richard Baxter's praise of Boyle's "pious Meditations \& Reflexions" implies that they have successfully achieved their spiritual intent; reading them, he claims in a letter to their author, calls him toward "greater Reverence ... as if I were in the Church." 39 Lady Ranelagh, who encourages her brother to publish further meditations in another edition, assures him that this kind of writing makes "a use of the creatures with refference to the glory of the Creator, or to beget Ingenious \& gratefull thoughts in the harts of men towards him," or in Baxter's phrasing, the "translating of the severall Creatures into a language understood." 40 The majority of the occasional meditations, however, do not praise God, and their intent is not always devotional. Unlike some 32 "Scripture-Reflections" and several 1647 occasional meditations that remained in manuscript, those shared with the public rarely turn to God. ${ }^{41}$ Where the meditations of Hall and especially many of Boyle's sister Mary Rich, Countess of Warwick, often importune the Lord in their resolution, only one of the Occasional Reflections addresses God, asking him for 
the means toward unwavering devotion (85-86). A meditation prompted by the meeting of two beggars leads to the desire, "Translate now (O my Soul) all this unto Spirituals" (57), and another on civility also turns to the soul (87); two more resolve in the first-person to be drawn toward God, one in trust and the other in love ( 56 , $90)$. But on the whole, though many raise religious considerations, the collection seems less devout than the conclusion of the Discourse might suggest. In an earlier essay "Of Piety," Boyle considers the "Morall Vertu" of piety rather than the virtue of divine worship; he defines heavenly mindedness in other early pieces as the ability to use the occasion to "serue vs for arguments or the augment of Vertu" and to curb faults before they become vices..$^{2}$ The conception of the pious and heavenly-minded in the meditations similarly retains this moral and spiritual focus.

In practice, the 40 reflections unrelated to those on the ague and angling have some tendency to moralize. The rhythm of observation, reflection, and application, which the Discourse defines as Protasis and Apodosis, in the nature of the genre moves toward closure. Those of Boyle seldom have the epigrammatic concision and wit that are a hallmark of Hall's meditations. Without pointed force they run some risk of lapsing into a moral tag. Boyle is capable of effective paradox, such as that ending the penultimate meditation in the collection; and he draws conclusions to an effective end with biblical passages and allusions, but the distinctiveness of his reflections lies less in the closure than in the occasions and discourses that lead to it.

The contexts of his meditations commonly have an extemporal immediacy. Boyle is sensitive in his Introduction to the criticism that too often in other meditations the "Subjects were Pretended" so that the "Conceits might be Accommodated," not prompted by the occasion (11). The reality of the ague and the explicitness of a morning spent angling have a counterpart in actual situations created in the other reflections. The formulaic "upon" that begins most seventeenth-century meditations seldom conveys the sense that the observation or occurrence is closely related to the reflector. The same objects and occasions reappear with some regularity in these publications; others may be found as well in emblem literature. Ten of Boyle's reflections, in fact, share similarities with Hall's, among them the meeting of beggars, kindling a fire, and contemplating a cloud, lute, lantern, and stars. Another "Upon the sight of the effects of a Burning-glass" imposes an opening generalization upon the object, succumbing to a pattern evident elsewhere among contemporaries. The collection stands apart from other publications, however, in the extent to which the meditative similitudes seem based upon his experience and actual events. The unrealized danger of death while riding in the Somerset hills of Mendip, the escape from a pirate's ship on a 1648 journey from the Netherlands, or the shooting of a 
crow at his Stalbridge estate are personal experiences, as are, to a lesser extent, the teasing of his dog with food, distilling the essence of roses, or riding in a coach. The mourning of the court in the Netherlands and the arrival of the Russian ambassador at the English court reveal in their public contexts the further lack of pretense.

In the letter praising the publication, Baxter refers to the "speciall way" in which his friend teaches readers to see in the "most ordinary" of daily occurrences "the signification (the use)" without undue straining of the imagination. ${ }^{43}$ Boyle has a homely ability to derive from the commonplace moral and spiritual meaning. The dog that continues to jump for the meat until it is given to him "Not unresemblingly" illustrates a reconciliation between justification by works and by faith: salvation can neither be reached by human effort nor achieved without the effort to gain heaven. At greater length and abstraction, other meditations expand the significance of the similitude. The prism that lends a rainbow of colour to the objects, seemingly transforming their nature, is likened in Boyle's understanding to Christ, who transfigures flawed human beings in the eyes of God and thereby endears them to him. Events also occasion extended analogy. The unusually wet and cold summer during the 1648 siege of Colchester, weather that might appear to have been caused by the civil upheaval, becomes in the lesson an encouragement to dispel spiritual winter with faith in the biblical sun of divine righteousness and comfort. Boyle's tendency to expatiate is further apparent in a number of meditations that incorporate dialogue into a form that was conventionally one of soliloquy. 44

His justification in the Discourse for dialogue rests upon the belief that it offers "a Scope for diversity of Opinions, for Debates, and for Replies" (10), giving dimension to the traditional notion of "conference with thy self." 45 The form of exchange essential to the dialectic in the reflections on angling, though absent in those on ague, develops in the course of the other meditations. Boyle's use of dialogue may have had a possible origin in the rumination after the unexpected stumbling of his horse on even ground. His reflection on his own attitude towards fortune, "But upon second Thoughts" (57), lends itself easily to the dialogue form. The first of the dialogues offers further opportunity for thought in the reactions of Eusebius and Lindamor to a windmill, though the responses themselves remain unrelated. The next dialogue adds Eugenius, and together the three come to understand the significance of a richly framed mirror. Lindamor's desire to hear Eugenius's views on the custom of court mourning and their disagreement about the authenticity of a gardener's apparent happiness move in subsequent meditations toward considered engagement. In all, eleven of the 40 meditations, increasingly those in the second half, are dialogues. At their most substantial 
and diverse they provide Boyle a means of self-representation and thoughtful expression both indirect yet immediate.

Dialogue offers the opportunity for personal revelation different from the first-person point of view in his other meditations. Despite a strong sense of autobiographical context, Boyle reveals little about himself in either the reflections or the resolutions. The exception, other than a self-conscious reference to "my Beardless Chin" in a piece dated 1648 and an early admission that fortune has not yet tested his constancy, is the reflection "Upon a Child that cri' $\mathrm{d}$ for the Stars." The little boy drawn futilely toward the twinkling firmament reminds Boyle of "my inclinations for Astronomy" that draw him out on cold, clear nights to gaze upon the stars with calm and serenity. When the meditation then turns to a contrast between an "amorous Disposition of mind" and the "rational Contentment" of an astronomer, Boyle, who never married, indirectly refers to his own commitment to natural philosophy and the trouble-free pleasure in "looking upon these curiousest Productions of Nature, with a Philosopher's and a Christian's Eyes" (161). Dialogue affords him further opportunity to reflect upon his own values and experiences, expressed at one remove by others. To a degree the participants, especially Eusebius, approximate an alter ego. Though the pretense of a distinction between them and the author is sustained when Lindamor's comments about custom remind Eugenius of "your Friend Mr. Boyle" and his desire to write a narrative (171), and when Eusebius tells Genorio "your Friend Mr. Boyle" would not be similarly moved by paintings of beautiful women displayed in a shop (181), further revelations about the author are implicit.

Comments in the dialogues about the moral and natural philosopher are particularly relevant. In a central discussion of writing, "Seeing a Child picking the Plums out of a piece of Cake" reminds Eusebius of the "unwelcome fate those Papers of mine, that treat of Devotion" met (167). His complaint about the folly of assuming that virtue and piety need no adornment and his account of the "self-denying" and failed efforts to craft an alternative to a plain style are heartfelt. Whether Boyle had in mind the reception of a specific work he had himself written, the tone and tenor of Eusebius's comments imply the misgivings are shared. Lindamor's response that eloquence must ultimately lie in the author's moral character, and worth in his intention, leads Eusebius to accept with some reservation the discouragement with which Boyle may have struggled to resolve as his writing was drawn into a public forum. Dialogue gives voice to an inner conflict without seeming overly self-indulgent. Dialogue also helps mitigate self-flattery in another exchange on the difficulties of authorship. The meditation implies through Eusebius that Boyle may be among the "studious persons, that you and I know" (158) and that the long 
recitation of the laborious demands and toil of writing has Boyle specifically in mind. The insistence at length on the knowledge and skills good writing requires and the uncertainty of its recompense reflects, it would seem, the author's doubts and frustrations. Any question about the possible relationship between Boyle and Eusebius disappears in the last of the dialogues and final meditation when Eusebius now refers to "my Meditations" and ends the collection by telling Lindamor, Genorio, and undoubtedly the reader that they must consider "the devouter passages you may have met with among my Composures, as Expressions of what I aim at, rather than of what I practice" (184).

All three dialogues, especially the first, are sensitive to the role wit and eloquence play in effective writing and the corollary danger of ornamentation. Boyle's ambivalence, most evident in "Upon sight of a Looking-glass, with a rich Frame," stems from the fundamental opposition he cites earlier between fancy and reason. In a reflection on the paring of a beautiful apple and the tension between its appearance and essence, Boyle argues the need to go beyond the delight of the eloquent and witty, to strip away the "flattering Ornaments" and "cheating Disguises" of fancy (61). He is less negative and more tolerant in a meditation on the "making of Syrup of Violets" in which he concedes the benefits that wit, eloquence, and learning "do naturally confer." Boyle recognizes that writing intended only to delight may prove a means of instruction in "Rational" and "well-meant design" and that some readers can only be instructed by compositions "tricked up with Flowers of Rhetorick" (149). ${ }^{6}$ The diverse responses to the richly framed mirror move through dialogue toward synthesis. The frame that draws viewers to the mirror is an apt metaphor for the attraction and limitations of "Wit, and fine Language" (88). To Eugenius's conclusion that eloquence, while not essential, may draw and engage the listener or reader and Lindamor's qualification that language, like the frame itself, should not be a measure of a sermon's worth, Eusebius adds his concerns about the failure to understand "true Representation." Preachers who become enamoured with language compromise the responsibility of their calling, and listeners who applaud the orator in the pulpit rather than the divine mistake rhetoric for "unedifying Discourses." Two other dialogues, one on the fashion of displaying expensive objects and the other on a shop filled with portraits, reinforce Boyle's uneasiness that eloquent and witty language may become mere ornamentation and vanity at odds with piety and devotion. It is fear of the seductive power of uncontainable fancy and imagination he defines in earlier moral essays as raving. ${ }^{47}$ Yet despite his misgivings, Boyle also recognizes in Occasional Reflections that "vary'd and surprizing Dress" skillfully employed in "ev'n slight and unpromising Occasions" may "procure" for virtue 
"lovers" (183). Though the possible sexual overtones of the word "procure" may connote an unresolved tension, the use of metaphoric language itself implies Boyle's understanding and approval of the affective force figurative language can give to moral and spiritual persuasion.

The meditations also show Boyle's willingness to examine his commitment to the pursuit of virtue. With considerable indirection he ponders whether a private or public life is more desirable. The question involves the choice between the contemplative or the active life, an issue that Baxter in his letter and Boyle in the angling narrative also raise. "Upon a Lanthorn and Candle carri' $d$ by, on a windy night" concedes the obligation to consider public service, though for many the moral risks may outweigh the good. Virtue shielded in a private life, while less publicly illuminating, is less likely to be extinguished or "blown out" (172). Loss of freedom also concerns Boyle. The glowworm caught at his sister Mary's Leigh estate represents for him an emblem of both "Rare Qualities" and "needless Ostentation of ones Excellencies" (154): scintillating wits and luminous minds in their conspicuousness, like that of the glowworm, can prove an undoing. Boyle's attention in particular to the fate of men whose considerable knowledge exposes them to unwelcome and confining attention may especially trouble him as he contemplates the growing public direction of his career. The pursuit of knowledge also has a personal danger Eusebius and Lindamor recognize in the fate of a lark caught in a net. The soaring bird drawn downward and into captivity by its attraction to light embodies the plight of the unwary philosopher. The exchange obviously has the author in mind. Eusebius warns Lindamor, "you have a Curiosity, or rather a Greediness of knowledge, that is impatient of being confin'd by any other Limits than those of Knowledge it self" (165), and he alludes to the illness that kept Lindamor for a time from the "enchanting Studies" that Eusebius fears would otherwise have enmeshed him. Through this warning voice, Boyle acknowledges that the innocent pleasure of learning can be seductive: the intellectual life consumed with the desire for knowledge must not ignore temptations on the journey toward heaven. Time and thought must also be given to the preparation for death. "We may visit Athens, but we should dwell at Jerusalem" (166).

At the conclusion of the last section Eusebius states that his many reflections may be rightly seen as "the productions, not of a constant frame of mind, but of Occasional Fits of Devotion” (183). Though Eusebius denies that his thoughts are exclusively pious or religious, the meditations Boyle gathered together suggest that he himself found the time to make good use of the parentheses in the direction his life was taking. From moments that often seem related to his experience, 
Boyle reveals a moral and spiritual sensitivity that gives personal dimension to the meditative format established in the seventeenth century. While some of the 40 reflections, notably those in the initial sections, resemble Hall's in their pattern of observation and resolution, others of greater length and less forceful closure recall Boyle's considerably longer moral essays. Together with the innovative dialogues, these lengthier discourses enhance his distinctive approach to reflection. Occasional meditations that contribute to an understanding of their art and others that comment on fashion, civility, custom, and decorum are unusual in the seventeenth century. The concerns about language, and their "thinking and reflecting," further set them apart. They are an expression of the sensibility and disposition that suit both the moral philosopher of his earlier writing and the natural philosopher of later renown. These meditations exemplify, however unevenly, the "way of thinking" Boyle advocates in the collection's Discourse. They are means whereby, in the words of Seneca, the mind may be "continually strengthened" as it contemplates "the secrets of nature" and "when we treat divine matters."

\section{NOTES}

1. Donald Lupton, "Vpon his reading the Occasionall Meditations of the Reverend Doctor Hals Composition," in Solitarinesse Improved, In occasional Meditations upon several Subjects (London, 1640), pp. 156-58; Lancelot Reynolds, Spiritvall Intervals, Or The Soules Exercise (London, 1641), A7r-v; Edmund Calamy, The Art of Divine Meditation (London, 1680), A2r; James Harrington, Horce Consecratee, or Spiritual Pastime (London, 1682), uuuu2r. Scholarship acknowledging Hall's contribution to seventeenth-century meditation includes Harold Fisch, "Bishop Hall's Meditations," Review of English Studies 25 (1949), pp. 210-21; Louis L. Martz, The Poetry of Meditation, rev. ed. (New Haven: Yale University Press, 1962); U. Milo Kaufmann, The Pilgrim's Progress and Traditions in Puritan Meditation (New Haven: Yale University Press, 1966); Barbara Kiefer Lewalski, Protestant Poetics and the Seventeenth-Century Religious Lyric (Princeton: Princeton University Press, 1979); Frank Livingstone Huntley, "Bishop Joseph Hall and Protestant Meditation," Studies in the Literary Imagination 10.2 (1977), pp. 57-71, and his edition Bishop Joseph Hall and Protestant Meditation in Seventeenth-Century England, ed. Frank Livingstone Huntley, Medieval \& Renaissance Texts \& Studies, vol. 1 (Binghamton: Center for Medieval and Early Renaissance Studies, 1981); Ronald J. Corthell, "Joseph Hall and Protestant Meditation," Texas Studies in Literature and Language 20.3 (1978), pp. 36785; Richard A. McCabe, Joseph Hall: A Study in Satire and Meditation (Oxford: Clarendon Press, 1982); Kate Narveson, "Godly Gentility as Spiritual Capital: The Appeal of Hall's Meditations in Early Stuart England," Explorations in Renaissance Culture 30.2 (2004), pp. 149-70. 
2. Robert Boyle, Occasional Reflections upon Several Svbiects Whereto is premis'd A Discourse Aboutsuch kind of Thoughts, in The Works of Robert Boyle, ed. Michael Hunter and Edward B. Davis, 14 vols. (London: Pickering \& Chatto, 1999-200o), vol. 5, p. 10. Hereafter cited in the text. In a discussion of "Boyle's Baconian methodology," Peter Anstey and Michael Hunter consider the "virtue of an unprepossessed mind"-in Boyle's words, "that I might not be prepossess'd with any Theory or Principles till I had spent some time in trying what Things would incline me to think" (pp. 105, 106, in "Robert Boyle's 'Design about Natural History," Early Science and Medicine 13.2 [2008], pp. 83-126).

3. Michael Hunter, "Introduction," Robert Boyle by Himself and His Friends, ed. Michael Hunter (London: Pickering \& Chatto, 1994), p. xvi; Malcolm Oster, "Millenarianism and the new science: the case of Robert Boyle," in Samuel Hartlib and the Universal Reformation: Studies in intellectual communication, ed. Mark Greenglas et al. (Cambridge: Cambridge University Press, 1994), p. 141. Hunter discusses the "apologies, complaints and whinges" common in Boyle's works in "Self-Definition through Self-Defence: Interpreting the Apologies of Robert Boyle," in Robert Boyle (1627-91) Scrupulosity and Science, ed. Michael Hunter (Woodbridge, Suffolk: The Boydell Press, 2000), pp. 135-53.

4. By focusing on these 40 occasional meditations, the following appreciation complements the discussion of the meditative mode in the quite different angling narrative; see Raymond A. Anselment, "Robert Boyle, Izaak Walton, and the Art of Angling," Prose Studies 30.2 (2008), pp. 124-41. Though different in focus, its analysis also supplements some of the observations Marie-Louise Coolahan makes about Boyle's contribution to the genre in "Redeeming Parcels of Time: Aesthetics and Practice of Occasional Meditation,” The Seventeenth Century 22.1 (2007), pp. 124-43.

5. Gilbert Burnet, “The 'Burnet Memorandum': notes by Gilbert Burnet on his biographical interview(s) with Boyle," in Robert Boyle by Himself and His Friends, p. 27.

6. Five of the six meditations now included in Unpublished writings, 1645-c. 1670 are dated either March or May, 1647 (The Works of Robert Boyle, vol. 13, pp. 115-16).

7. Joseph Hall, The Art of Divine Meditation, in Bishop Joseph Hall and Protestant Meditation in Seventeenth-Century England, ed. Frank Livingstone Huntley, p. 73; William Gearing, The Mount of Holy Meditation (London, 1662), p. 30.

8. Joseph Hall, p. 72.

9. Richard Baxter, A Christian Directory: Or, A Summ of Practical Theologie, and Cases of Conscience (London, 1678), Book One, p. 257.

10. Richard Rogers, The Practice of Christianitie. Or, an Epitomie of seuen Treatises, penned and published in the yeere 1603 (London, 1618), p. 262.

11. Isaac Ambrose, Media: the Middle Things (London, 1657), p. 219; John Ball, A Treatise of Divine Meditation (London, 1660), pp. 77-78.

12. "Boyle's Library," in The Early Essays and Ethics of Robert Boyle, ed. John T. Harwood (Carbondale and Edwardsville: Southern Illinois University Press, 1991), p. 255. Michael Hunter has questioned the ownership of the books Harwood lists as part 
of Boyle's library, contending that the basis of the attribution "is at best inconclusive" and that it "seems far likelier" that the books belonged to Boyle's servant John Warr ("Appendix 2: Boyle's Library," in Michael Hunter et al., The Boyle Papers: Understanding the Manuscripts of Robert Boyle [Aldershot: Ashgate Publishing Limited, 2007], pp. 71-72).

13. Burnet states in "Memorandum" that this Senecan work "first set him on Naturall Philosophy" (Robert Boyle by Himself and His Friends, p. 26). In another context Michael Hunter also cites Burnet and recognizes Boyle's affinity with Seneca and "the moral value of a proper understanding of the natural world" (Boyle Between God and Science [New Haven: Yale University Press, 2009], p. 50).

14. Steven Shapin, among others, notes that "Boyle continued to publish moral and theological tracts to the end of his life, and into the eighteenth century he enjoyed a substantial reputation as a moralist," in Shapin, "Personal development and intellectual biography: the case of Robert Boyle," The British Journal for the History of Science 26.3 (1993), p. 338. In a major contribution to Boyle studies, Boyle Between God and Science, Michael Hunter illuminates the ways in which Boyle's "shift to science was stimulated by an overwhelmingly religious impulse" (252)," a commitment in which Christianity remained "arguably the central fact of his life" (204) and "science and theology were truly complementary" (254). Edward B. Davis provides a general overview in "Robert Boyle's Religious Life, Attitudes, and Vocation," Science \& Christian Belief 19.2 (2007), pp. 117-38.

15. The first sentence in the passage, "Omnibus Rebus, omnibusque Sermonibus, aliquid Salutare miscendum est," in Thomas Lodge's seventeenth-century translation is "For in all things, and in all speeches, we ought to intermix somewhat that is wholesome and profitable" (The Workes of Lvcivs Anncevs Seneca Newly Inlarged and Corrected by Thomas Lodge D. M. P. [London, 1620(?)], p. 807). Thomas H. Corcoran translates the same sentence in the Loeb series, "Some moral ought to be mixed in all things and all conversation” (Naturales Quaestiones, in Seneca in Ten Volumes [Cambridge: Harvard University Press, 1971], vol. 7, p. 193).

16. Boyle draws on an earlier essay, "Of the Study of the Booke of Nature": "the Study of Nature is the Noblest Memoria Localis of a Christian, \& that he may turne the whole World into a Conclave Mnemonicum: God having every where trac't such instructive Hieroglyphicks" (The Works of Robert Boyle, vol. 13, p. 168).

17. See, for example, George Swinnock, The Christian-Mans Calling: or, A Treatise of Making Religion ones Business ... The Third and last Part (London, 1665), pp. 451, 383. Others that emphasize the study of nature's creatures, if not always specifically its book, include Joseph Hall, pp. 73-74; Reynolds, A11v-12r; Ball, pp. 84-85; William Bridge, Christ And the Covenant The Work and way of Meditation (London, 1667), p. 437; Nathanael Ranew, Solitude Improved by Divine Meditation (London, 1670), pp. 27-28, 144; Calamy, pp. 7-8.

18. Thomas Taylor, Meditations From The Creatures (London, 1632), p. 104; Reynolds, A7v; Swinnock, p. 452; Calamy, p. 14. 
19. Contemporaries that liken meditation to the bee that gathers "Celestial sweetness" do not draw the distinction between the bee and the ant. See Thomas Watson, $A$ Christian On the Mount: Or, a Teatise [sic] concerning Meditation, in The Saints Delight (London, 1657), pp. 85-86; Ranew, p. 29; Edward Bury, The Husbandmans Companion (London, 1677), A3r.

20. Thomas White, A Method and Instructions for the Art of Divine Meditation (London, 1672), p. 14; Calamy, p. 18; Richard Allestree, The Whole Duty of Divine Meditation, Described In all its various Parts and Branches (London, 1694), pp. 1-2.

21. Robert Hall, “The Dedicatory Epistle,” in Occasional Meditations, in Bishop Joseph Hall and Protestant Meditation in Seventeenth-Century England, p. 121. In "Redeeming Parcels of Time," Coolahan stresses the Protestant concern about the "Losse of Time,” p. 125.

22. Boyle, "Of Time and Idleness," p. 241, and "The Doctrine of Thinking," p. 194, in The Early Essays and Ethics of Robert Boyle.

23. Cf. Boyle's concern about the "Losse of those Interuals [and (as it were Parentheses)] of Time, which interuene like Enterludes in Playes, betweene the more serious /acts/ Bisness of our Liues," in "Of Time and Idleness," in The Early Essays and Ethics of Robert Boyle, p. 240.

24. Reynolds, A4r; Swinnock, pp. 442, 452; Watson, p. 250; William Spurstow, The Spiritual Chymist: Or, Six Decads [sic] Of Divine Meditations On several Subjects (London, 1666), A3v; Calamy, p. 7.

25. Joseph Hall, p. 71; Reynolds, A4r; Ball, p. 21; Watson, p. 250; John Flavell, Husbandry Spiritualized: Or, The Heavenly Use of Earthly Things (London, 1669), a2r; Calamy, p. 6; Bury, A3v.

26. Ball, p. 78. See also White, p. 45; Allestree, pp. 26-27. Issues of style concerned Boyle in much of his writing; see, for example, Steven Shapin, "Pump and Circumstance: Robert Boyle's Literary Technology," Social Studies of Science 14 (1984), pp. 481-520, esp. 494-97; Robert Markley, "Robert Boyle on Language: Some Considerations Touching the Style of the Holy Scriptures," in Studies in Eighteenth-Century Culture, vol. 14, ed. O. M. Brack, Jr. (Madison: The University of Wisconsin Press, 1985), pp. 159-71; John T. Harwood, "Science writing and writing science: Boyle and rhetorical theory," in Robert Boyle reconsidered, ed. Michael Hunter (Cambridge: Cambridge University Press, 1994), pp. 37-56, esp. 48-52; Lawrence M. Principe, "Style and Thought of the Early Boyle: Discovery of the 1648 Manuscript of Seraphic Love," Isis 85 (1994), pp. 247-60; Michael Wintroub, “The Looking Glass of Facts: Collecting, Rhetoric and Citing the Self in the Experimental Natural Philosophy of Robert Boyle," History of Science 35 (1997), pp. 189-217, esp. 192-95; Coolahan, esp.pp. 132-135.

27. Samuel Butler, "An Occasional Reflection on Dr. Charlton's feeling a Dog's Pulse at Gresham-College. By R. B. Esq.," in Satires and Miscellaneous Poetry and Prose, ed. René Lamar (Cambridge: Cambridge University Press, 1928), pp. 341-43; Jonathan Swift, "A Meditation upon a Broom-stick: According to The Style and Manner of the 
Honourable Robert Boyle's Meditations," in The Prose Works of Jonathan Swift, ed. Herbert Davis, 14 vols. (Oxford, 1939-68), vol. 1, pp. 239-40. In The Mount of Holy Meditation Gearing notes that some unnamed people "have spoken against this manner of meditation and instruction, saying, that herein we let out our thoughts upon every base creature; but I say, unlesse a man will be wilfully blind, this way he will be made to understand; and God would not that we should look on earthly things without a holy and spirituall application" (33).

28. Reynolds, A12v; Ball, p. 85; Gearing, pp. 31-33; Bury, A3v; Flavell, A3r.

29. Ball, p. 84 .

30. Joseph Hall, p. 72; Rogers, p. 261.

31. Thomas Gouge, Christian Directions Shewing How to walk with God All the Day long (London, 1661), p. 37; Ranew, p. 202; Ball, p. 77. See also Ambrose, p. 216; Jeremy Taylor, "Of Meditation," in The Whole Works of the Right Rev. Jeremy Taylor, D.D., ed. Reginald Heber and rev. Charles Page Eden, 10 vols. (London: Longman et al., 184754), vol. 2, pp. 130, 131.

32. Gearing, pp. 25-26; Watson, pp. 71-72.

33. Boyle's meditations, however, do not reveal the "almost mystical sense of the role of the study of nature in raising man's mind towards God" that Michael Hunter sees in Boyle's essay "Of the Study of the Book of Nature" ("How Boyle Became a Scientist," History of Science 33 [1995], p. 68). See also Markley, p. 161.

34. Gouge, Christian Directions, p. 38.

35. Richard Baxter, The Saints Everlasting Rest, 8th ed. (London, 1659), p. 704.

36. Joseph Hall, 87; Calamy, 175.

37. Swinnock, pp. 454-55. Colossians 3:2, "Set your affection on things above, not on things on the earth," provides a biblical basis for the phrase, which often in seventeenth-century interpretations of heavenly mindedness has an element of contemptus mundi. Substantial considerations include John Rowe, Heavenly-mindedness, and Earthly-mindedness (London, 1672), and Thomas Gouge, "Of Heavenly-mindedness," in A Word to Sinners, And a Word to Saints (London, 1668), pp. 193-203.

38. Baxter, The Duty of Heavenly Meditation (London, 1671), p. 7; Ranew, pp. 208, 204.

39. Richard Baxter's 14 June 1665 letter in The Correspondence of Robert Boyle, 1636-1691, ed. Michael Hunter et al., 6 vols. (London: Pickering \& Chatto, 2001), vol. 2, p. 473.

40. Katherine Jones's 29 July 1665 letter in The Correspondence of Boyle, vol. 2, p. 499; Baxter's 14 June 1665 letter, vol. 2, p. 476.

41. The reflections on biblical passages along with the six meditations are included in Unpublished writings, 1645-c. 1670, in The Works of Robert Boyle, vol. 13, pp. 101-16.

42. Boyle, "Of Piety," p. 169; Artelology, pp.90-91; and “The Dayly Reflection,” p. 206, in The Early Essays and Ethics of Robert Boyle.

43. Baxter, 14 June 1665 letter in The Correspondence of Robert Boyle, vol. 2, p. 476.

44. Ball, p. 9; Swinnock, p. 432.

45. Swinnock, p. 432 . 
46. In the Discourse Boyle "will not say" whether the current fashions in attire among gallants "might not warrant the tricking up of slight subjects, with the richer Ornaments of Language" (14).

47. In "The Doctrine of Thinking," Boyle reacts against "thoughts that are built vpon, [vnlikely or] impossible, vnlikely or vseless suppositions <hypotheses>, (which is) commonly cald Rauing which is nothing but a Play or a Romance personated <acted $>$ in the Braine /Imagination/" (The Early Essays and Ethics of Robert Boyle, 192). See also, among others, Harwood's discussion of "raving" in this edition, xlviii-xlix. 